九州大学学術情報リポジトリ

Kyushu University Institutional Repository

\title{
Evaluation of Resistance in Rice Plants to Myanmar Isolates of Xanthomonas oryzae pv. oryzae
}

Aye, Se int San

Institute of Tropical Agriculture, Kyushu University

Matsumoto, Masaru

Institute of Tropical Agriculture, Kyushu University

Kaku, Hisatoshi

National Institute of Agrobiological Resources

Goto, Takahiro

Faculty of Agriculture, Kyushu University

他

https://doi.org/10.5109/9274

出版情報：九州大学大学院農学研究院紀要. 52 (1)，pp.17-21，2007-02-28. Faculty of Agriculture， Kyushu University

バージョン :

権利関係 : 


\title{
Evaluation of Resistance in Rice Plants to Myanmar Isolates of Xanthomonas oryzae pv. oryzae
}

\author{
Seint San AYE ${ }^{1}$, Masaru MATSUMOTO*1, Hisatoshi KAKU ${ }^{2}$, Takahiro GOTO ${ }^{3}$, \\ Naruto FURUYA ${ }^{3}$ and Aatsushi YOSHIMURA ${ }^{4}$
}

Institute of Tropical Agriculture, Kyushu University, Fukuoka 812-8581, Japan

(Received November 9, 2006 and accepted December 1, 2006)

\begin{abstract}
To obtain genetic resources of resistance to bacterial leaf blight of rice caused by Xanthomonas oryzae pv. oryzae in Myanmar, 40 Myanmar rice varieties, 10 international differentials of near isogenic lines and 17 varieties of pyramided lines were tested for the resistance to three different pathotypes isolated in Myanmar. The bacterial isolate used were MKM13 (belonging to predominant race in Myanmar and showing wide range of pathogenicity), M 3-1 (showing intermediate range of pathogenicity) and MKM39 (belonging to rare race in Myanmar and showing narrow range of pathogenicity). The fully developed leaves at maximum tillering stage were used for inoculation of each isolate. Three weeks after the inoculation scoring was made according to the lesion length. The reaction was considered as S (susceptible) when the lesion length was more than $5 \mathrm{~cm}$, while considered as R (resistant) when it was $5 \mathrm{~cm}$ below. In the inoculation test using international differentials of near isogenic lines, the resistance genes, Xa21 and Xa3, would be effective resistant resources to the bacterial blight diseases in Myanmar. Although bacterial isolate MKM39 was avirulent to IR24, some Myanmar varieties were susceptible to this isolate. Rice varieties cultivated in Myanmar were classified into four groups based on their reactions to three Myanmar bacterial isolates. Group I contained one variety was resistant to all the three isolates of pv. oryzae and group II contained 14 varieties was susceptible. Group III contained 23 varieties resistant to bacterial isolate MKM39 but susceptible to MKM13 and M3-1. Group IV contained two varieties was susceptible to bacterial isolate MKM13 but resistant to M3-1 and MKM39. Furthermore, gene combinations $\mathrm{Xa3}+\mathrm{Xa} 7, \mathrm{Xa} 3+$ $X a 10, X a 4+x a 5$ and $X a 4+x a 5+X a 13+X a 21$ conferred a broad spectrum of resistance to all three Myanmar isolates evaluated, supporting the strategy of pyramiding appropriate resistance genes.
\end{abstract}

\section{INTRODUCTION}

Bacterial blight of rice caused by Xanthomonas oryzae pv. oryzae is a widespread and destructive disease in irrigated and rain fed environments of Asia (Mew, 1987; Ou, 1985). Yield losses due to bacterial blight disease are thought to be higher in tropical Asian counties containing Myanmar than in temperate area countries (Mizukami and Wakimoto, 1969; Ou, 1985) because virulent populations of this pathogen become to the prevalent in the tropical area (Buddenhagen and Reddy, 1972; Wakimoto, 1967). Moreover, the local and improved varies are highly susceptible to the disease. High yielding cultivars introduced from China are particularly susceptible to the disease. Thus, the development of resistant rice varieties is urgent subject in order to control this disease (Ezuka and Sakaguchi, 1978; Mew and Khush, 1981) because effective and economical bactericides against this disease have not been developed. Host resistance is an important component of an integrated disease management program for bacterial disease. So far, 24 resistance genes have been identified

${ }^{1}$ Institute of Tropical Agriculture, Kyushu University, Fukuoka 812-8581, Japan

${ }^{2}$ National Institute of Agrobiological Resources, Kannondai, Tsukuba 305-8602, Japan

${ }^{3}$ Department of Applied Genetics and Pest Management, Faculty of Agriculture, Kyushu University, Fukuoka 812-8581, Japan

${ }^{4}$ Departoment of Plant Breeding, Fuculty of Agriculture, Kyushu University, Fukuoka 812-8581, Japan

* Corresponding author (E-mail: mmatsu@agr.kyushu-u.ac.jp) and utilized in rice breeding programs (Ogawa et al., 1991; McCouch et al., 1991; Ronald et al., 1992; Yoshimura et al., 1992 and 1995; Borines et al., 2000). Although many sources of resistance to bacterial blight have been identified in rice-growing countries in Asia (Khush, 1989; Ogawa, 1991), breeding rice for resistance to $X$. oryzae pv. oryzae in Myanmar is still in an early developmental stage. In Myanmar, five races of $X$. oryzae pv. oryzae were identified and rice varieties were classified into 8 groups (Lwin et al., 1992). The purpose of this study is to identify resistance sources for controlling the rice bacterial blight in Myanmar.

\section{MATERIALS AND METHODS}

Rice varieties and preparation of plants: Forty native rice cultivars from different locations of Myanmar indicated in Fig. 1, more over 10 international differentials of near-isogenic lines, and 17 varieties of pyramided lines were also used. Myanmar rice varieties were collected by Central Agriculture Research Centre, Yezin, Myanmar. IR24 was used as a susceptible check. Seeds were sown in plastic seedboxes using drybed method and then transplanted individually to pots at 4-5 leaf stage and were grown in the greenhouse. Fertilizer and insecticides were applied according to the standard method of managing rice plants.

Bacterial isolates: Three Myanmar bacterial isolates were used for inoculation tests and described their characteristics as follows (Kaku et al., 2004). Bacterial isolate MKM 13 is a predominant race in Myanmar and 


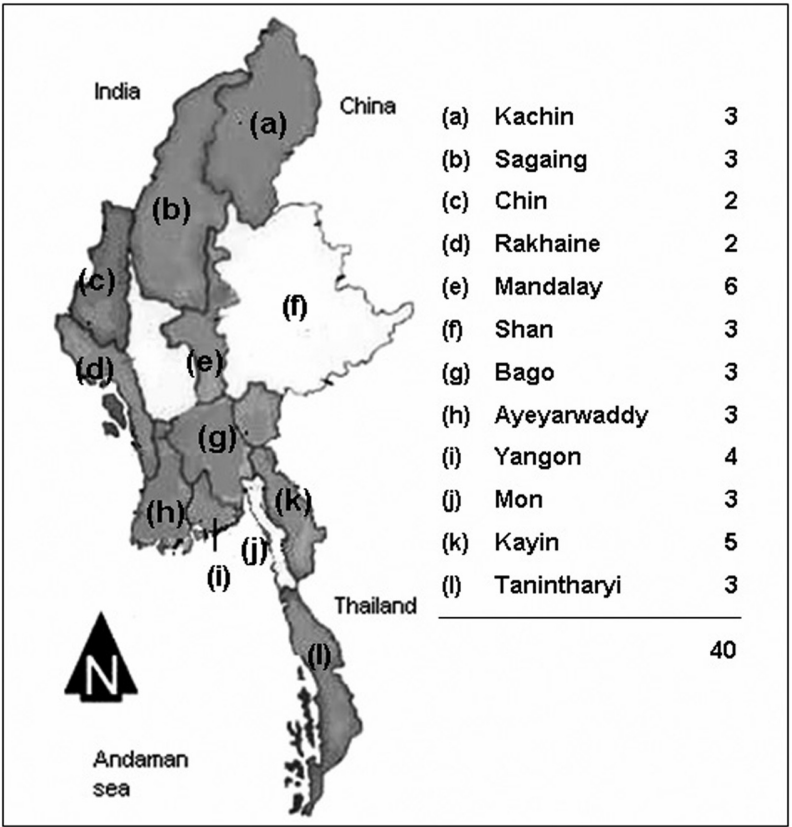

Fig. 1. Distribution of Myanmar cultivars used in this experiment

shows the wide range of pathogenicity. M 3-1 is a intermediate range of pathogenicity. MKM 39 is a rare race in Myanmar and expresses a very narrow range of pathogenicity. Each isolate was maintained in $15 \%$ glycerol at $-80 \mathrm{C}$ until use.

Inoculum preparation and inoculation: Three Myanmar isolates of $X$. oryzae pv. oryzae that were maintained at $-80 \mathrm{C}$ were revived on potato semi-synthetic agar medium (PSA) (Wakimoto, 1955) plates at $28^{\circ} \mathrm{C}$ for $72 \mathrm{hr}$. Each isolate was transferred to PSA slants and incubated an additional $48 \mathrm{hr}$ at $28^{\circ} \mathrm{C}$. Inoculum of each isolate was prepared by suspending the bacterial cells in $10 \mathrm{ml}$ of sterilized distilled water and adjusted to approximately $10^{9} \mathrm{cfu} / \mathrm{ml}$. Plant materials for inoculation were used at maximum tillering stage. Plants in a pot were bundled with three groups by bounding with different colored-ties in order to dis- tinguish the inoculated isolates. Inoculation was done according to the clipping method with scissors described by Kauffman et al. (1973). The inoculated plants were then grown in greenhouse at $25-30{ }^{\circ} \mathrm{C}$ for three weeks. Disease reaction was assessed with the lesion length from the position of inoculation site. Lesion length was measured at 21 days after inoculation and data for one variety was decided to the average of 4 or 5 inoculated leaves. Disease reaction was categorized according to the lesion length, in which 0 to $5 \mathrm{~cm}$ was classified as resistant (R) and more than $5 \mathrm{~cm}$ was classified as susceptible (S).

\section{RESULTS}

\section{Reactions of near-isogenic lines}

Interactions between near-isogenic lines and three isolates are shown in Table 1. The degree of disease reaction in this experiment showed different relationship between combinations of rice varieties and bacterial isolates. Bacterial isolate MKM 13 showed an broad range of pathogenicity and M 3-1 expressed moderate range of pathogenicity. Cultivar IR 24, which has no major functional gene for resistance to the Philippine isolates, was used as susceptible check. However, MKM 39 was avirulent to all the varieties of near isogenic lines. IRBB3 (Xa3) and IRBB21 (Xa21) were resistant to all three bacterial isolates.

\section{Evaluation of Myanmar rice cultivars}

Forty Myanmar cultivars were tested for their resistance to the three isolates. As shown in Fig. 2, Myanmar rice cultivars could be divided into four groups (group I-IV) according to reaction pattern to the three Myanmar isolates. Thirty-seven Myanmar cultivars belonged to type II and III were susceptible to bacterial isolates M13 and M3-1. One Myanmar variety belonged to type I, Nga Yar Pauk, was expressed resistant reaction to the three isolates (Table 2). Although bacteria isolate MKM39 was avirulent to IR 24, fourteen Myanmar cultivars were susceptible to the isolate.

Table 1. Reaction ${ }^{\text {a) }}$ of near isogenic lines to Myanmar isolates of $X$. oryzae pv. oryzae

\begin{tabular}{|c|c|c|c|c|}
\hline \multirow{2}{*}{ Name of lines } & \multirow{2}{*}{ Genes involved } & \multicolumn{3}{|c|}{ Disease reaction and lesion length $(\mathrm{cm})$ to bacterial isolate } \\
\hline & & MKM 13 & M3-1 & MKM39 \\
\hline IR 24 & - & $\mathrm{S}(17.1)$ & S (12.6) & $\mathrm{R}(0.5)$ \\
\hline IRBB 1 & Xa1 & S (10.8) & $\mathrm{S}(7.8)$ & $\mathrm{R}(0.5)$ \\
\hline IRBB2 & Xa1, Xa2 & $\mathrm{S}(11.3)$ & $\mathrm{S}(7.6)$ & $\mathrm{R}(0.5)$ \\
\hline IRBB 3 & $X a 3$ & $\mathrm{R}(3.2)$ & $\mathrm{R}(1.4)$ & $\mathrm{R}(0.5)$ \\
\hline IRBB 4 & $\mathrm{Xa}_{4}$ & $\mathrm{~S}(11.9)$ & $\mathrm{R}(1.8)$ & $\mathrm{R}(0.5)$ \\
\hline IRBB 5 & $x a 5$ & $\mathrm{~S}(9.6)$ & $\mathrm{R}(0.9)$ & $\mathrm{R}(0.5)$ \\
\hline IRBB 7 & Xa7 & $\mathrm{S}(9.0)$ & $\mathrm{R}(0.5)$ & $\mathrm{R}(0.5)$ \\
\hline IRBB 10 & Xa10 & S (13.7) & $\mathrm{S}(9.0)$ & $\mathrm{R}(0.5)$ \\
\hline IRBB 11 & Xa11 & $\mathrm{S}(11.4)$ & $\mathrm{S}(8.8)$ & $\mathrm{R}(0.5)$ \\
\hline IRBB 14 & $\mathrm{Xa14}$ & $\mathrm{S}(10.6)$ & $\mathrm{S}(7.6)$ & $R(0.5)$ \\
\hline IRBB 21 & Xa21 & $\mathrm{R}(0.9)$ & $\mathrm{R}(2.3)$ & $\mathrm{R}(0.5)$ \\
\hline
\end{tabular}

a) Reaction at tillering stage, $\mathrm{R}$ : resistant, $\mathrm{S}$ : susceptible 


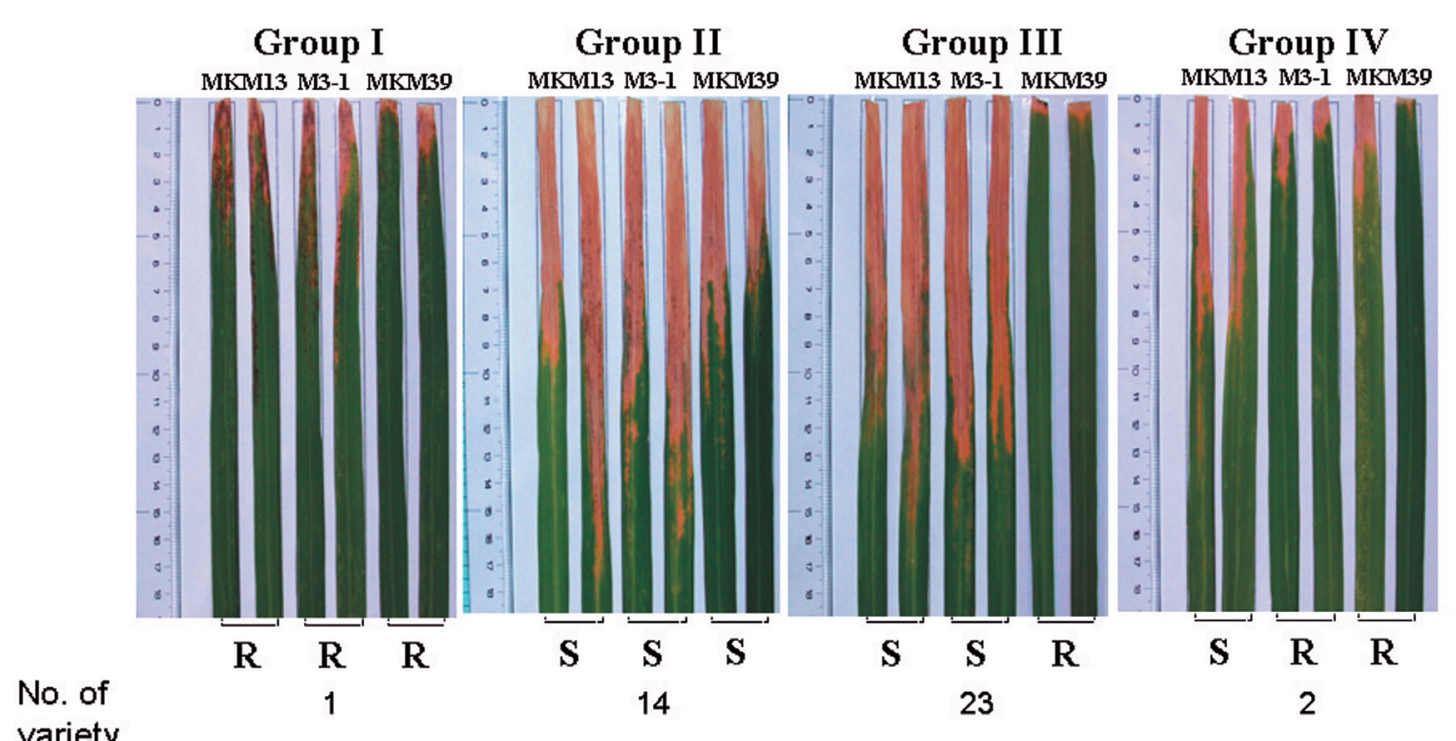

Fig. 2. Disease reaction patterns to Myanmar bacterial isolates

Table 2. Reaction of Myanmar rice varieties to the Myanmar bacterial isolates of X. oryzae pv. oryzae

\begin{tabular}{|c|c|c|c|c|c|}
\hline \multirow{2}{*}{ Local varieties name } & \multirow{2}{*}{ Region } & \multirow{2}{*}{$\begin{array}{c}\text { Disease reaction } \\
\text { groups }\end{array}$} & \multicolumn{3}{|c|}{ Disease reaction and Lesion length $(\mathrm{cm})$ to bacterial isolate } \\
\hline & & & MKM 13 & M3-1 & MKM39 \\
\hline ho Kaw Gyi & Yangon Division & III & $\mathrm{S}(6.8)$ & $\mathrm{S}(11.8)$ & $R(5.0)$ \\
\hline Pho Kaw Lay & Yangon Division & II & $\mathrm{S}(12.3)$ & $\mathrm{S}(11.2)$ & $\mathrm{S}(7.6)$ \\
\hline Na Kywe & Yangon Division & II & $\mathrm{S}(6.8)$ & $\mathrm{S}(10.0)$ & $\mathrm{R}(5.0)$ \\
\hline Thone Hnan Pwa & Yangon Division & III & $\mathrm{S}(10.3)$ & $\mathrm{S}(10.8)$ & $\mathrm{R}(4.3)$ \\
\hline Sein Kamakyi & Bago Division & III & $\mathrm{S}(8.7)$ & $\mathrm{S}(9.8)$ & $\mathrm{R}(1.4)$ \\
\hline Kywet Thwa & Bago Division & III & $\mathrm{S}(11.8)$ & $\mathrm{S}(14.3)$ & $\mathrm{R}(2.3)$ \\
\hline Shwe Dinga & Bago Division & II & $\mathrm{S}(11.7)$ & S (13.7) & S (7.6) \\
\hline Let Yone Gyi & Ayeyarwady Division & III & $\mathrm{S}(14.3)$ & $\mathrm{S}(17.4)$ & $\mathrm{R}(3.7)$ \\
\hline Nga Kywe Phyu & Ayeyarwady Division & III & $\mathrm{S}(12.1)$ & $\mathrm{S}(12.4)$ & $\mathrm{R}(0.3)$ \\
\hline Hnan Kar & Ayeyarwady Division & III & $\mathrm{S}(13.1)$ & $\mathrm{S}(13.5)$ & $\mathrm{R}(2.6)$ \\
\hline Law Thaw Phin Me & Mandalay Division & II & $\mathrm{S}(14.5)$ & $\mathrm{S}(17.0)$ & $\mathrm{S}(8.9)$ \\
\hline Shwe Bo Taing Hteik Pan & Mandalay Division & III & $\mathrm{S}(9.6)$ & $\mathrm{S}(10.9)$ & $R(3.8)$ \\
\hline Ok Shit Phyu & Mandalay Division & II & $\mathrm{S}(12.0)$ & $\mathrm{S}(14.0)$ & $\mathrm{S}(6.8)$ \\
\hline Pin Shwe War & Mandalay Division & III & $\mathrm{S}(15.6)$ & $\mathrm{S}(18.2)$ & $\mathrm{R}(0.2)$ \\
\hline Kalar Htun & Mandalay Division & II & S (16.8) & S (17.8) & $\mathrm{S}(10.3)$ \\
\hline Thone Hnan Latt & Mandalay Division & II & $\mathrm{S}(13.0)$ & $\mathrm{S}(13.3)$ & $\mathrm{S}(7.7)$ \\
\hline Yin Ka Lay & Tanintharyi Division & III & $\mathrm{S}(16.3)$ & $\mathrm{S}(17.9)$ & $\mathrm{R}(0.2)$ \\
\hline Wun Htauk & Tanintharyi Division & II & $\mathrm{S}(14.5)$ & $\mathrm{S}(12.4)$ & $\mathrm{S}(6.3)$ \\
\hline Kyauk Htu & Tanintharyi Division & III & $\mathrm{S}(12.5)$ & $\mathrm{S}(12.0)$ & $\mathrm{R}(4.4)$ \\
\hline A Pyo Chaw & Sagaing Division & III & $\mathrm{S}(12.9)$ & $\mathrm{S}(12.5)$ & $\mathrm{R}(3.4)$ \\
\hline Kyauk Latt Phyu & Sagaing Division & II & $\mathrm{S}(15.5)$ & $\mathrm{S}(14.1)$ & $\mathrm{R}(0.2)$ \\
\hline Tay Lay & Sagaing Division & $\mathrm{IV}$ & $S(10.6)$ & $\mathrm{R}(1.6)$ & $\mathrm{R}(0.8)$ \\
\hline Khao Mu Si & Shan State & III & $\mathrm{S}(16.0)$ & $\mathrm{S}(17.8)$ & $\mathrm{R}(0.2)$ \\
\hline Khai Man Mu & Shan State & II & S (15.8) & $\mathrm{S}(15.1)$ & $\mathrm{S}(5.1)$ \\
\hline Khao Sa Lwe & Shan State & II & $\mathrm{S}(19.9)$ & S (18.1) & $\mathrm{S}(5.9)$ \\
\hline Aung Ze Ya & Mon State & III & $\mathrm{S}(10.3)$ & $\mathrm{S}(14.5)$ & $\mathrm{R}(0.2)$ \\
\hline Ekariin Kwa & Mon State & III & $S(11.6)$ & S (13.7) & $\mathrm{R}(0.2)$ \\
\hline Kari Let Yone & Mon State & III & S (20.7) & S (18.4) & $\mathrm{R}(0.2)$ \\
\hline Khun Naya Po & Kachin State & III & $\mathrm{S}(6.5)$ & $\mathrm{S}(16.6)$ & $\mathrm{R}(4.9)$ \\
\hline Moe Thay & Kachin State & II & S (18.7) & $\mathrm{S}(17.3)$ & $\mathrm{S}(11.1)$ \\
\hline Chin $\mathrm{Pa}$ ahee & Kachin State & II & $\mathrm{S}(9.7)$ & $\mathrm{S}(12.5)$ & $\mathrm{S}(6.7)$ \\
\hline Daw Tit & Chin State & II & S (19.8) & $\mathrm{S}(17.5)$ & $\mathrm{S}(5.2)$ \\
\hline In Gar & Chin State & III & $\mathrm{S}(16.5)$ & $\mathrm{S}(15.3)$ & $\mathrm{R}(0.6)$ \\
\hline Ekayin Kwa & Kayin State & III & $\mathrm{S}(10.2)$ & $\mathrm{S}(14.1)$ & $\mathrm{R}(3.8)$ \\
\hline Ekayin Saw & Kayin State & IV & $\mathrm{S}(9.8)$ & $\mathrm{R}(0.6)$ & $\mathrm{R}(0.8)$ \\
\hline Lala Gyi & Kayin State & III & $\mathrm{S}(12.6)$ & $\mathrm{S}(16.1)$ & $\mathrm{R}(0.5)$ \\
\hline Gaung To & Kayah State & II & $\mathrm{S}(12.7)$ & $\mathrm{S}(16.1)$ & $\mathrm{S}(8.6)$ \\
\hline Nga Yar Pauk & Kayah State & I & $\mathrm{R}(4.8)$ & $\mathrm{R}(5.0)$ & $\mathrm{R}(1.5)$ \\
\hline Ohn Ni Ma & Rakhine State & III & $\mathrm{S}(10.1)$ & $\mathrm{S}(13.0)$ & $\mathrm{R}$ (1.8) \\
\hline $\mathrm{Sa} \mathrm{O} \mathrm{MeP}$ & Rakhine State & II & S (16.7) & S (15.6) & $\mathrm{S}(8.9)$ \\
\hline
\end{tabular}

R: resistant S: susceptible 


\section{Reaction of Pyramiding lines to Myanmar isolates}

As can be seen in Table 3, gene pyramidings with four gene combinations $\mathrm{Xa3}+\mathrm{Xa} 4, \mathrm{Xa3}+\mathrm{Xa10}, \mathrm{Xa} 4+$ $x a 5$ and $X a 4+x a 5+x a 13+X a 21$ were resistant to all the isolates. Lesion lengths on gene pyramids were significantly shorter than single-gene near-isogenic lines even though the gene pyramids were inoculated with isolates that were virulent to individual $\mathrm{Xa}$ genes. The pyramids were significantly more resistant to all isolates than their respective individual $X a$ gene. For example, complimentary gene action was observed in Xał $(11.9 \mathrm{~cm})$ or $x a 5(9.6 \mathrm{~cm})$ where both single genes are susceptible to bacterial isolate MKM13, but the gene pyramid $\left(X_{4} 4+x a 5\right)$ show significantly shorter lesion.

\section{DISCUSSION}

The identification of useful resistance genes through virulence analysis will support a gene deployment approach to managing the disease using resistant cultivars. On the basis of host-pathogen interaction, Myanmar rice varieties were classified into four groups. Almost of Myanmar cultivars were belonged to type II and III which were susceptible to bacterial isolates M13 and M3-1. Among 40 Myanmar varieties, cv. Nga Yar Pauk from Kayah division was resistant to the three Myanmar bacterial isolates. This variety will be useful for rice breeding resource.

Although bacterial isolate MKM39 was avirulent to IR24 which carries no major resistance gene except Xa16 and Xa18, fourteen Myanmar cultivars belonging to type II were susceptible to this isolate. The results indicated that IR24 may harbor an additional resistance gene or genes to MKM39. Similar results were observed by Endo and Ogawa (2004), and Noda et al. (1996).

In this study, we evaluated a set of lines with gene combinations in IR24 background, along with their individual genes, for their reaction to all the isolates. Interestingly, the line with $\mathrm{Xa} \psi+x a 5$ were resistance to MKM13 that were virulent to single genes (Xa4 and xa5), presumably due to the complementary action of the resistance genes.

As a result, IRBB 3 (Xa3), IRBB 21 (Xa21), IRBB3/7 (Xa3 + Xa7), IRBB3/10 (Xa3 + Xa10), IRBB4/5 $(X a 4+x a 5)$, IRBB4/5/13/21 $(X a 4+x a 5+x a 13+X a 21)$ and Nga Yar Pauk were resistant to all the isolates tested. Therefore, a breeding program should be initiated to transfer these resistance genes from the differential varieties to high quality Myanmar rice varieties to control the disease effectively.

\section{REFERENCES}

Borines, L. M., C. M. Veracruz, E. D. Redona, J. F. Hernandez, M. P. Natural, A. D. Raymundo and H. Leung 2000 Marker aided pyramiding of bacterial blight resistance genes in maintainer lines for hybrid rice production. IRRI Conf Abstr. 4: 162

Buddenhagen, I. W. and A. P. K. Reddy 1972 The host, the environment, Xanthomonas oryzae and the researcher. Pages 289-295 in Rice breeding. International rice research Institute, P. O. Box 933, Manila, Philippines

Endo, N. and T. Ogawa. 2004 Myanmar: a relative outsider to the primary gene center based on its different bacterial blight resistance genes. Abstracts. The $1^{\text {st }}$ International Conference on Bacterial Blight of Rice. 12

Ezuka, A. and S. Sakaguchi 1978 Host- parasite relationship in bacterial blight of rice caused by Xanthomonas oryzae. Rev. Plant Prot. Res. 11: 93-118

Kaku, H., S. S. Myint, Y. T. Tun, K. Irie, H. Ochiai and T. Noda 2004 Race Distribution of Xanthomonas oryzae pv. oryzae in Myanmar. Jpn. J. Phytopathol. 70: 286 (abstr. in japanease)

Kaku, H. 1993 Infection types in rice - Xanthomonas campestris pv. oryzae interaction. Jpn. Agric. Res. Q. (JARAQ) 27: 81-87

Kauffman, H. E., A. P. K. Reddy, S. P.Y. Hsieh and S. D. Merca

Table 3. Reaction of pyramiding lines to Myanmar isolates to the Myanmar isolates of X. oryzae pv. oryzae

\begin{tabular}{|c|c|c|c|c|}
\hline \multirow{2}{*}{ Name of lines } & \multirow{2}{*}{ Genes involved } & \multicolumn{3}{|c|}{ Disease reaction and Lesion length $(\mathrm{cm})$ to bacterial isolate } \\
\hline & & MKM 13 & M3-1 & MKM39 \\
\hline IR 24 & & $\mathrm{~S}(17.1)$ & $\mathrm{S}(12.6)$ & $\mathrm{R}(0.5)$ \\
\hline IRBB 1/4 & Xa1, Xa4 & $\mathrm{S}(9.3)$ & $R(1.5)$ & $\mathrm{R}(0.5)$ \\
\hline IRBB $1 / 5$ & $X a 1, x a 5$ & $\mathrm{~S}(6.7)$ & $\mathrm{R}(0.9)$ & $\mathrm{R}(0.5)$ \\
\hline IRBB 1/7 & Хa1, Хar & $\mathrm{S}(11.6)$ & $R(0.5)$ & $\mathrm{R}(0.5)$ \\
\hline IRBB 1/10 & Xa1, Xa10 & $\mathrm{S}(9.6)$ & $\mathrm{S}(9.5)$ & $\mathrm{R}(0.5)$ \\
\hline IRBB 1/11 & Xa1, Xa11 & $\mathrm{S}(5.7)$ & $\mathrm{R}(5.0)$ & $\mathrm{R}(0.5)$ \\
\hline IRBB $3 / 7$ & Хаз, Хa7 & $\mathrm{R}(0.9)$ & $\mathrm{R}(0.5)$ & $\mathrm{R}(0.5)$ \\
\hline IRBB 3/10 & Хаз, Хa10 & $\mathrm{R}(2.7)$ & $\mathrm{R}(0.5)$ & $\mathrm{R}(0.5)$ \\
\hline IRBB 4/5 & Xa4, xa5 & $\mathrm{R}(3.9)$ & $\mathrm{R}(0.5)$ & $\mathrm{R}(0.5)$ \\
\hline IRBB 4/7 & Xa4, Xa7 & $\mathrm{S}(5.3)$ & $R(0.5)$ & $\mathrm{R}(0.5)$ \\
\hline IRBB 4/10 & Xa4, Xa10 & $\mathrm{S}(6.1)$ & $\mathrm{R}(0.5)$ & $\mathrm{R}(0.5)$ \\
\hline IRBB 4/11 & Xa4, Xa11 & $\mathrm{S}(5.1)$ & $\mathrm{R}(0.5)$ & $\mathrm{R}(0.5)$ \\
\hline IRBB 5/7 & xa5, Хa7 & $\mathrm{S}(8.8)$ & $\mathrm{R}(0.5)$ & $\mathrm{R}(0.5)$ \\
\hline IRBB 5/10 & $x a 5$, Xa10 & $\mathrm{S}(12.4)$ & $R(0.5)$ & $\mathrm{R}(0.5)$ \\
\hline IRBB 5/11 & $x a 5$, Xa11 & $\mathrm{S}(13.8)$ & $\mathrm{R}(0.5)$ & $\mathrm{R}(0.5)$ \\
\hline IRBB 7/10 & Xa7, Xa10 & $\mathrm{S}(13.3)$ & $\mathrm{R}(0.5)$ & $\mathrm{R}(0.5)$ \\
\hline IRBB 10/11 & Xa10, Xa11 & $\mathrm{S}(10.5)$ & $\mathrm{S}(11.1)$ & $\mathrm{R}(0.5)$ \\
\hline IRBB 4/5/13/21 & $X a-4 / x a-5 / x a 13 / 21$ & $R(0.5)$ & $R(0.5)$ & $\mathrm{R}(0.5)$ \\
\hline
\end{tabular}

R: resistant S: susceptible 
1973 An improved technique for evaluating resistance of rice varieties to Xanthomonas oryzae. Plant Disease Reptr. 57: $537-541$

Khush, G. S., D. J. Mackill and G. S. Sindhu 1989 Breeding rice resistance to bacterial blight. Pages 207-217 in: Bacterial Blight of Rice. International Rice Research Institute, Manila, Philippines

Lwin, T., K. Htay, H. Myint and A. Baw 1992 Race Xanthomonas oryzae pv. oryzae (Pathogen of bacterial leaf blight of rice) and varietal resistance of rice to different races. Myanmar J. Agr. Sc. 4: $32-46$

McCouch, S. R, M. L. Abenes, E. R. Angels, G. S. Khush and S. D. Tanksley 1991 Molecular tagging of a recessive gene, $x a-5$, conferring resistancce to bacterial blight of rice. Rice Genet News 8: $143-145$

Mew, T. W. and G. S. Khush 1981 Breeding for bacterial blight resistance in rice Proc. $5^{\text {th }}$ Int. Conf. Plant Pathologic Bact. CIAT. Cali. Colombia. 504-510

Mew, T. W. 1987 Current status and future prospects of research on bacterial blight of rice. Annu. Rev. Phytopathol. 25: 359-382

Mizukami, T. and S. Wakimoto 1969 Epidemiology and control of bacterial leaf blight of rice. Annu. Rev. Phytopathol. 7: 51-72

Noda, T., T. Yamamoto, T. Ogawa and H. Kaku 1996 Pathogenic races of Xanthomonas oryzae pv. oryzae in south and east
Asia. JIRCAS Journal 3: 9-15

Ogawa, T., T. Yamamoto, G. S. Khush and T. W. Mew 1991 Breeding of near-isogenic lines of rice with ingle genes for resistance to bacterial blight pathogen (Xanthomonas campestris pv. oryzae). Jpn. J. Breed. 41: 523-529

Ou, S. H. 1985 Rice diseases. Common wealth Mycological Institute, Kew, Surrey, United Kingdom. 380

Ronald, P. C., B. Albano, R. Tabien, L. Abenes, K. Wu, S. R. McCouch and S. D. Tanksley (1992). Genetic and physical analysis of the bacterial blight disease resistance locus, Xa-21. Mol. Gen. Genet. 236: 113-120

Wakimoto, S. 1967 Strains of Xanthomonas oryzae in Asia and their virulence against rice varieties. Pages 19-24 in Proceedings of the symposium on rice diseases and their control by growing resistant varieties and other measures. Agricultural Forestry and Fisheries Research Council, Ministry of Agriculture and Forestry, Tokyo, Japan.

Wakimoto, S. 1955 Studies on the multiplication of OP1 phage (Xanthomonas oryzae bacteriophage) 1. One-step growth experiment under various conditions. Sci. Bull. Fac. Agric. Kyushu Univ. 15: 151-160

Yoshimura, S., A. Yoshimura, N. Iwata, S. R. McCouch, M. L. Rbenes, M. R. Baraoidan, T. W. Mew and R. J. Nelson 1995 Tagging and combining bacterial blight resistance gene in rice using RAPD and RFLP markers. Mol. Breed. 1: 375-387 